\title{
BACTERIOCIN PRODUCTION BY LACTOBACILLUS PLANTARUM AMA-K ISOLATED FROM AMASI, A ZIMBABWEAN FERMENTED MILK PRODUCT AND STUDY OF THE ADSORPTION OF BACTERIOCIN AMA-K TO LISTERIA SP.
}

\author{
Svetoslav D. Todorov \\ Department of Microbiology, University of Stellenbosch, Stellenbosch, South Africa
}

Submitted: August 14, 2007; Returned to authors for corrections: October 17, 2007; Approved: January 23, 2008.

\begin{abstract}
Bacteriocin AMA-K produced by Lactobacillus plantarum AMA-K inhibits the growth of Enterococcus spp., Escherichia coli, Klebsiella pneumoniae and Listeria spp. Growth of strain AMA-K in BHI, M17, soy milk and molasses was similar to growth in MRS. The effect of organic nitrogen sources, carbohydrates, glycerol, $\mathrm{K}_{2} \mathrm{HPO}_{4}$ and $\mathrm{KH}_{2} \mathrm{PO}_{4}, \mathrm{MgSO}_{4}, \mathrm{MnSO}_{4}$, tri-ammonium citrate, Tween 80, vitamins and initial $\mathrm{pH}$ on bacteriocin AMA-K was determined. The mode of action of bacteriocin AMA-K was studied. The effect of bacteriocin AMA-K to actively growing Listeria innocua LMG13568, L. ivanovii subsp. ivanovii ATCC19119 and $L$. monocytogenes ScottA was determined. Adsorption of bacteriocin AMA-K to target cells at different temperatures, $\mathrm{pH}$ and in presence of Tween 20 , Tween 80 , ascorbic acid, potassium sorbate, sodium nitrate and sodium chloride were studied. Bacteriocin AMA-K shares high homology to pediocin PA-1.
\end{abstract}

Key words: Bacteriocin AMA-K; Lactobacillus planatrum; Amasi

\section{INTRODUCTION}

Amasi is a traditional fermented milk product consumed in different regions of Southern African, including Zimbabwe, South Africa and Lesotho. The product is an unsweetened curd with a consistency slightly thicker than yoghurt and with a $\mathrm{pH}$ between 3.6 and 4.2. Although normally consumed with thick corn-meal porridge, Amasi is also consumed between meals with ground sorghum, similar to muesli.

Traditionally Amasi is produced from unpasteurised bovine (cow's) milk and is allowed to ferment spontaneously in an earthenware (clay) pot or gourd ("calabash") for two to three days at ambient temperature. The microbial flora responsible for the fermentation is derived from the air, raw milk and walls of the containers. After coagulation, the whey is drained through a plugged hole at the bottom of the container.

Fermentation is dominated by lactic acid bacteria (Lactobacillus plantarum, Lactobacillus helveticus, Lactococcus lactis subsp. lactis, Leuconostoc lactis, Leuconostoc citreum, Leuconostoc mesenteroides subsp. dextranicum, Lactobacillus delbrueckii subsp. lactis, Lactobacillus casei subsp. casei and Lactobacillus casei subsp. pseudoplantarum) typically in the order of $10^{8} \mathrm{CFU} / \mathrm{ml}(4)$.

Lactic acid bacteria are known for their production of antimicrobial compounds, including bacteriocins or bacteriocinlike peptides (10). Bacteriocins of LAB are defined as ribosomally synthesized proteins or protein complexes usually antagonistic to genetically closely related organisms (10). In previous work the characterization of a bacteriocin produced by Lactobacillus plantarum AMA-K was described (43). Bacteriocins are generally low molecular weight proteins that gain entry into target cells by binding to cell surface receptors. Their bactericidal mechanism vary and may include pore formation, degradation of cellular DNA, disruption through specific cleavage of $16 \mathrm{~S}$ rDNA, and inhibition of peptidoglycan syntesis $(10,15)$.

In recent papers $(23,29)$, specific environmental conditions, including those found in food, have been studied to determine their effect on the production of bacteriocins. Bacteriocin production changes dramatically upon altering of

*Corresponding Author. Mailing address: Department of Microbiology, University of Stellenbosch, 7600 Stellenbosch, South Africa. Tel.: +27-218085850. Fax: +27-21-8085846. E-mail: todorov@sun.ac.za 
environmental conditions and optimum production may require a specific combination of environmental parameters (22). Little is known about the interactions these factors have on the production of a bacteriocin, especially in a complex food environment.

Apart from studies conducted on the effect of nitrogen and carbon sources on the production of plantaricin ST31 (37), plantaricin 423 (46), plantaricin UG1 (13), plantaricin KW30 (19), plantaricin-149 (18), plantaricin S (16), plantaricin ST13BR (44) and plantaricin A (8), little is known about the growth conditions required for optimal production of these bacteriocins. Studies conducted on bacteriocins from other lactic acid bacteria, e.g. pediocin AcH (5), pediocin PD-1 (30), enterocin 1146 (32), enterocin AS-48 (2), enterocin P (14), sakP (1), and bacteriocins produced by Leuconostoc mesenteroides L124 (26) have shown that production is often regulated by growth $\mathrm{pH}$ and temperature. In some cases, higher bacteriocin activity has been recorded at sub-optimal growth conditions $(1,3,6,11,20,21,27,28,32,33,37)$.

The aim of this study was to determine the conditions needed for optimal production and study some aspects of mode of action of bacteriocin AMA-K produced by L. plantarum AMA$\mathrm{K}$ isolated from Amasi.

\section{MATERIALS AND METHODS}

\section{Bacterial strains and growth conditions}

Strain AMA-K, isolated from Amasi produced in Gwanda, Kafusi, in the South-Western region of Zimbabwe, was classified as L. plantarum based on phenotypic and genotypic characteristics (43). The strain was cultured in MRS medium (Biolab, Biolab Diagnostics, Midrand, SA) at $30^{\circ} \mathrm{C}$ and stored at $-80^{\circ} \mathrm{C}$ in spent MRS broth, supplemented with $15 \%(\mathrm{v} / \mathrm{v})$ glycerol. MRS broth (Biolab) was used in all experiments, except growth optimization, in which case MRS broth (9) was modified as indicated.

\section{Bacteriocin bioassay}

Bacteriocin screening was performed by using the agarspot-test method (34). Correction of the cell-free supernatant to $\mathrm{pH} 6.0$ with $1 \mathrm{M} \mathrm{NaOH}$ prevented the inhibitory effect of lactic acid. Antimicrobial activity was expressed as arbitrary units $(\mathrm{AU} / \mathrm{mL})$, calculated as $\mathrm{a}^{\mathrm{b}} \mathrm{x} 100$, where "a" represents the dilution factor and " $b$ " the last dilution that produces an inhibition zone of at least $2 \mathrm{~mm}$ in diameter. Activity is expressed per $\mathrm{mL}$ by multiplication with 100 . One AU is defined as the reciprocal of the highest dilution showing a clear zone of growth inhibition (34). Listeria innocua LMG13568 was used as indicator strain.

Cell-free supernatant containing bacteriocin AMA-K was incubated at $25^{\circ} \mathrm{C}$ for $68 \mathrm{~h}$ and at regular intervals bacteriocin activity was determined as described before.

\section{Bacteriocin production in different growth media and at different initial growth $\mathrm{pH}$}

An 18h-old culture of strain AMA-K was inoculated (2\%, $\mathrm{v} / \mathrm{v}$ ) into MRS broth (Biolab), BHI broth, M17 broth (Merck), soy milk $(10 \%, \mathrm{w} / \mathrm{v}$, soy flour) and molasses $(10 \%, \mathrm{w} / \mathrm{v})$, respectively. Incubation was at $30^{\circ} \mathrm{C}$ and $37^{\circ} \mathrm{C}$, respectively, without agitation, for $25 \mathrm{~h}$. Samples were taken every hour and examined for bacterial growth (OD at $600 \mathrm{~nm}$ ), changes in culture $\mathrm{pH}$, and production of bacteriocins $(\mathrm{AU} / \mathrm{mL})$. The agarspot-test method was used, with $L$. innocua LMG13568 as target organism.

In a separate experiment, the effect of initial medium $\mathrm{pH}$ on the production of bacteriocin AMA-K was determined. Volumes of $300 \mathrm{~mL}$ MRS broth were adjusted to $\mathrm{pH} 4.5,5.0$, 5.5, 6.0 and 6.5 , respectively, with $6 \mathrm{M} \mathrm{HCl}$ or $6 \mathrm{M} \mathrm{NaOH}$ and then autoclaved. Each flask was inoculated with $2 \%(\mathrm{v} / \mathrm{v})$ of an $18 \mathrm{~h}$-old culture of L. plantarum AMA-K and incubated at $30^{\circ} \mathrm{C}$ for $24 \mathrm{~h}$, without agitation. Changes in culture $\mathrm{pH}$ and production of bacteriocin AMA-K, expressed as AU/mL, were determined every hour as described elsewhere. All experiments were done in triplicate.

\section{Effect of medium composition on bacteriocin production}

L. plantarum AMA-K was grown in $10 \mathrm{~mL}$ MRS broth (Biolab) for $18 \mathrm{~h}$ at $30^{\circ} \mathrm{C}$, the cells harvested by centrifugation (8000x $\mathrm{g}, 10 \mathrm{~min}, 4^{\circ} \mathrm{C}$ ), and the pellet re-suspended in $10 \mathrm{~mL}$ sterile peptone water. Four $\mathrm{ml}$ of the cell suspension was used to inoculate $200 \mathrm{~mL}$ of the following media: (a) MRS broth (9), without organic nutrients, supplemented with tryptone $(20.0 \mathrm{~g} /$ $\mathrm{L})$, meat extract $(20.0 \mathrm{~g} / \mathrm{L})$, yeast extract $(20.0 \mathrm{~g} / \mathrm{L})$, tryptone $(12.5 \mathrm{~g} / \mathrm{L})$ plus meat extract $(7.5 \mathrm{~g} / \mathrm{L})$, tryptone $(12.5 \mathrm{~g} / \mathrm{L})$ plus yeast extract $(7.5 \mathrm{~g} / \mathrm{L})$, meat extract $(10.0 \mathrm{~g} / \mathrm{L})$ plus yeast extract $(10.0 \mathrm{~g} / \mathrm{L})$, or a combination of tryptone $(10.0 \mathrm{~g} / \mathrm{L})$, meat extract $(5.0 \mathrm{~g} / \mathrm{L})$ and yeast extract $(5.0 \mathrm{~g} / \mathrm{L})$, respectively; (b) MRS broth, i.e. with 20.0g/L D-glucose; (c) MRS broth without D-glucose, supplemented with $20.0 \mathrm{~g} / \mathrm{L}$ fructose, sucrose, lactose, mannose, maltose and gluconate, respectively; (d) MRS broth with 5.0 to $50.0 \mathrm{~g} / \mathrm{L}$ glucose as sole carbon source; (e) MRS broth with 2.0 to $20.0 \mathrm{~g} / \mathrm{L} \mathrm{K}_{2} \mathrm{HPO}_{4}, 2.0$ to $20.0 \mathrm{~g} / \mathrm{L} \mathrm{KH}_{2} \mathrm{PO}_{4}$ or combination of $2.0 \mathrm{~g} / \mathrm{L} \mathrm{K} \mathrm{K}_{2} \mathrm{HPO}_{4}$ and $2.0 \mathrm{~g} / \mathrm{L} \mathrm{KH}_{2} \mathrm{PO}_{4}$; (f) MRS broth supplemented with 1.0 to $50.0 \mathrm{~g} / \mathrm{L}$ glycerol; (g) MRS broth without $\mathrm{MgSO}_{4}$; (h) MRS broth without $\mathrm{MnSO}_{4}$; (i) MRS broth without or supplemented with $5.0 \mathrm{~g} / \mathrm{L}$ and $10.0 \mathrm{~g} / \mathrm{L}$ tri-ammonium citrate; and (j) MRS broth without Tween 80 or supplemented with 0.5 to $2.0 \mathrm{~g} / \mathrm{L}$.

In a separate experiment, the vitamins cyanocobalamin (Sigma, St. Louis, Mo.), L-ascorbic acid (BDH Chemicals Ltd), thiamine (Sigma) and DL-6,8-thioctic acid (Sigma) were filtersterilised and added to MRS broth at $1.0 \mathrm{mg} / \mathrm{mL}$ (final concentration). All cultures were incubated at $30^{\circ} \mathrm{C}$ for $24 \mathrm{~h}$ Activity levels of bacteriocin AMA-K were determined as described elsewhere. All experiments were done in triplicate. 


\section{Cell lysis}

In a separate experiment, $20 \mathrm{~mL}$ cell-free supernatant containing bacteriocin AMA-K (12800AU/ml, $\mathrm{pH} 6.0)$ was filtersterilized $(0.20 \mu \mathrm{m}$, Minisart $₫$, Sartorius) and added to $100 \mathrm{ml} 3$ h-old cultures $\left(\mathrm{OD}_{600}=0.1-0.2\right)$ of L. innocua LMG13568, Listeria monocytogenes ScottA and Listeria ivanovii subsp. ivanovii ATCC19119, respectively. Incubation was on BHI broth (Biolab) at $37^{\circ} \mathrm{C}$. Optical density readings were recorded at $600 \mathrm{~nm}$, hourly for $12 \mathrm{~h}$. The experiment was repeated with stationary-phase cells.

\section{Adsorption of bacteriocin AMA-K to target cells}

Adsorption of bacteriocin AMA-K to target cells was performed according to the method described by Yildirim $\mathrm{et} \mathrm{al}$. (47). The target strains (L. innocua LMG13568, $L$. monocytogenes ScottA and L. ivanovii subsp. ivanovii ATCC19119) were grown overnight in BHI broth at $37^{\circ} \mathrm{C}$ and then centrifuged $\left(8000 \mathrm{xg}, 15 \mathrm{~min}, 4^{\circ} \mathrm{C}\right.$ ). Cells were washed twice with sterile $5 \mathrm{mM}$ phosphate buffer (pH 6.5) and re-suspended in the same buffer to OD at $600 \mathrm{~nm}$ equal to 1.0. The $\mathrm{pH}$ was adjusted to 6.5 with sterile $0.1 \mathrm{M} \mathrm{NaOH}$. Each cell suspension was mixed with an equal volume bacteriocin AMA-K (12800AU/ $\mathrm{ml}, \mathrm{pH} 6.5$ ) and incubated at $37^{\circ} \mathrm{C}$ for $1 \mathrm{~h}$. After removal of cells (8000x $, 15 \mathrm{~min}, 25^{\circ} \mathrm{C}$ ), the activity of unbound bacteriocin AMA-K in the supernatant was determined as described before. All experiments were done in duplicate.

The percentage adsorption of bacteriocin AMA-K to target cells was calculated according to the following formula:

$$
\% \text { adsorption }=\left[100-\frac{A U / m L_{1}}{A U / m L_{2}}\right] \times 100
$$

$A U / m L_{1}$ refers to the bacteriocin activity after treatment; $A U / m L_{0}$ refers to the original (before treatment) activity.

\section{Effect of $\mathrm{pH}$ and temperature on the adsorption of bacteriocin AMA-K}

Bacteriocin AMA-K was added to $L$. innocua $\mathrm{LMG13568,} L$. monocytogenes ScottA and L. ivanovii subsp. ivanovii ATCC19119, as described elsewhere, and incubated for $1 \mathrm{~h}$ at 4 , $15,30,37$ and $45^{\circ} \mathrm{C}$, respectively $(\mathrm{pH} 7.0)$, and at $37^{\circ} \mathrm{C}$ at $\mathrm{pH} 3.5$, 5.5 and 7.0. Cells were harvested $\left(8000 \mathrm{xg}, 15 \mathrm{~min}, 25^{\circ} \mathrm{C}\right)$ and the $\mathrm{pH}$ of the cell-free supernatant adjusted to 6.0 with sterile $1 \mathrm{M}$ $\mathrm{NaOH}$. Bacteriocin activity in the supernatant was determined as described before. The experiments were done in duplicate.

\section{Effect of inorganic salts and organic compounds on adsorption of bacteriocin AMA-K to target cells}

Cells of L. innocua LMG13568, L. monocytogenes ScottA and L. ivanovii subsp. ivanovii ATCC19119 were treated with $1 \%(\mathrm{~m} / \mathrm{v})$ Tween 20 , Tween $80, \mathrm{NaCl}$, ascorbic acid, potassium sorbate and sodium nitrate. The $\mathrm{pH}$ of all samples were adjusted to 6.5 with $1 \mathrm{M} \mathrm{NaOH}$ or $1 \mathrm{M} \mathrm{HCl}$. Bactericoin AMA-K was added to the treated cells, as described before, and incubated for $1 \mathrm{~h}$ at $37^{\circ} \mathrm{C}$. The cells were harvested $\left(8000 \mathrm{xg}, 15 \mathrm{~min}, 25^{\circ} \mathrm{C}\right)$ and the activity of bacteriocin AMA-K in the cell-free supernatant determined as described before. The experiments were done in duplicate.

\section{Identification of genes encoding bacteriocin production}

DNA was isolated according to the method of Dellaglio $e t$ al. (12). Primers PEDRPO (5'-CAA GAT CGTTAACCA GTTT3') and PEDC1041 (5'-CCG TTG TTC CCA TAG TCT AA-3') were designed from the operon encoding pediocin PA-1 (Accession number M83924). PCR reactions were performed using a GeneAmp ${ }^{\circledR}$ PCR Instrument System 9700 (Applied Biosystems, Foster City, USA). The following conditions were used: an initial denaturation step of $94^{\circ} \mathrm{C}$ for $1 \mathrm{~min}$, followed by 35 cycles of $1 \mathrm{~min}$ at $94^{\circ} \mathrm{C}, 30 \mathrm{sec}$ at $50^{\circ} \mathrm{C}$ and $1 \mathrm{~min}$ at $72^{\circ} \mathrm{C}$, and final extension at $72^{\circ} \mathrm{C}$ for $5 \mathrm{~min}$. The amplified product was visualized in a $0.8 \%(\mathrm{w} / \mathrm{v})$ agarose gel stained with ethidium bromide. A band corresponding to the correct size was purified from the gel using the QIAquick PCR purification kit (QIAGEN $\mathrm{GmbH})$. Purified PCR product was subject to restriction enzyme digestion with $\mathrm{XhoI}$ and HindIII. The digested product was visualized in a $0.8 \%(\mathrm{w} / \mathrm{v})$ agarose gel stained with ethidium bromide.

PCR purified products were ligated into pGEM-T ${ }^{\oplus}$ Easy Vector (Promega, Madison, USA) and transformed into E. coli DH5 $\alpha$ according to instructions of the manufacturer. Plasmids were isolated using a QIAGEN Plasmid Mini Kit and fragments sequenced on an automatic sequencer (ABI Genetic Analyzer 3130XI, Applied Biosystems) using bigdye terminator chemistry (Biosystem, Wanington, England). Sequences were analysed using DNAMAN for Windows ${ }^{\circledR}$ (Lynnon Biosoft, Quebec, Canada).

\section{RESULTS AND DISCUSSION}

All data represent an average of two or three repeats. The values recorded in each experiment did not vary by more than $5 \%$ and single data points are presented in the figures without standard deviation bars.

The cell-free supernatant of $L$. plantarum AMA-K inhibited the growth of E. faecalis, E. mundtii, E. coli, K. pneumoniae, $L$. lactis subsp. lactis, L. casei, L. curvatus and L. sakei (54), and E. faecium, L. innocua, L. monocytogenes and $L$. ivanovii subsp. ivanovii. According to tricine-SDS-PAGE, bacteriocin AMA-K is approximately $2.9 \mathrm{kDa}(43)$.

Growth of L. plantarum AMA-K in BHI, M17, soy milk and molasses was very similar to growth in MRS (Fig. 1). The cell density of both strains increased from $\mathrm{OD}_{600 \mathrm{~nm}} 0.03$ to approximately 9.8 (dilution factor taken into calculation) during 36h (Fig. 1). Low levels of bacteriocin AMA-K activity (less 


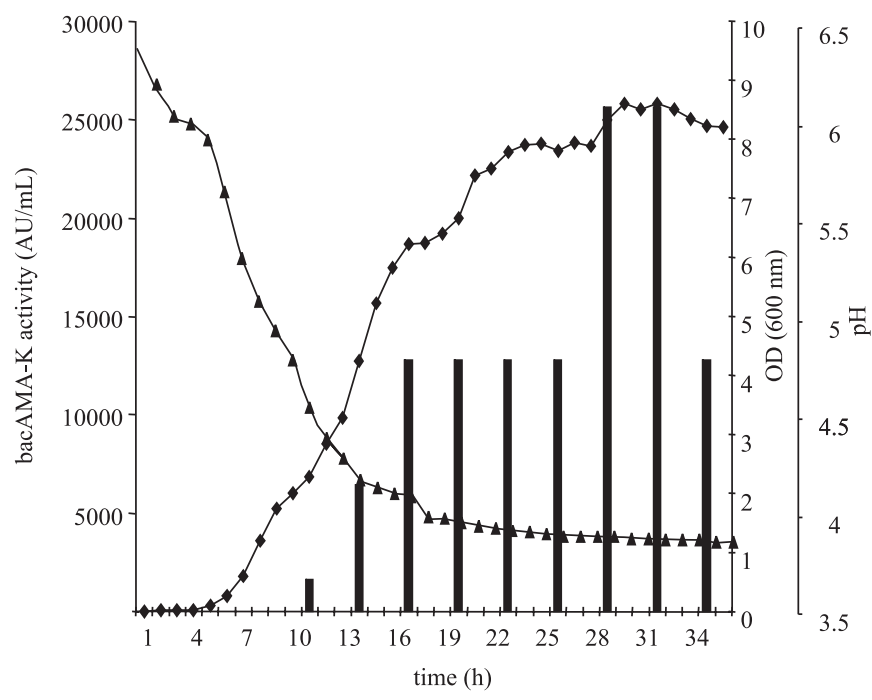

Figure 1. Growth of L. plantarum AMA-K ( - $\downarrow$ - ), production of bacteriocin AMA-K ( - bars - ) and changes in pH ( - $\boldsymbol{\Delta}$ - ) in MRS broth (Biolab).

than 200AU/mL) were detected after $8 \mathrm{~h}$ of growth in MRS broth (Fig. 1). Optimal production of bacteriocin AMA-K (25600AU/mL) was recorded after 29h (Fig. 1), and only when incubated at $30^{\circ} \mathrm{C}$ or $37^{\circ} \mathrm{C}$. Bacteriocin AMA-K is a primary metabolite. Similar results have been reported for bacteriocin ST151BR (35), plantaricin Y (7) and bacteriocins produced by $P$. acidilactici (31).

The activity of bacteriocin AMA-K did not decrease during $68 \mathrm{~h}$ of incubation at $25^{\circ} \mathrm{C}$, suggesting that extracellular proteases have not been produced. Optimal bacteriocin production (12800AU/mL) was recorded in MRS broth with an initial $\mathrm{pH}$ of 6.0 and 5.5 (Table 1). In MRS broth (pH 6.5) supplemented with $1 \mathrm{mM}$ EDTA, bacteriocin AMA-K production was 12800AU/ $\mathrm{mL}$, suggesting that the bacteriocin was not effected by proteases. Low levels of bacteriocin activity were recorded when the strains were cultured in MRS broth with an initial $\mathrm{pH}$ of 5.0 and 4.5 (3200AU/mL and 6400AU/mL, respectively, Table 1). The culture $\mathrm{pH}$ after $24 \mathrm{~h}$ growth was between 3.45 and 3.60. Similar results have been reported for other bacteriocins produced by L. plantarum $(8,16,37)$.

Growth of L. plantarum AMA-K in BHI broth or M17 broth adjusted to $\mathrm{pH} 6.5$ yielded only 1600AU/mL of bacteriocin AMA$\mathrm{K}$ (Table 2). No bacteriocin production was recorded in $10 \%$ (w/ v) soy milk or $2 \%(\mathrm{w} / \mathrm{v})$ molasses (Table 2). Low levels of bacteriocin AMA-K $(800 \mathrm{AU} / \mathrm{mL})$ were recorded when the strains were grown in $10 \%$ (w/v) molasses (Table 2). Specific nutrients are required for the production of the bacteriocin AMA-K. This phenomenon has been observed for other bacteriocins, e.g. bacteriocins ST194BZ, ST414BZ and ST664BZ, produced by different strains of L. plantarum $(36,41)$.
Table 1. Influence of initial medium $\mathrm{pH}$ on production of bacteriocin AMA-K in MRS broth (Biolab).

\begin{tabular}{lccccc}
\hline & \multicolumn{5}{c}{ Initial pH } \\
\cline { 2 - 6 } & 4.50 & 5.00 & 5.50 & 6.00 & 6.50 \\
\hline $\begin{array}{l}\text { Final pH } \\
\begin{array}{l}\text { Bacteriocin activity } \\
(\mathrm{AU} / \mathrm{mL})\end{array}\end{array}$ & 3.45 & 3.52 & 3.60 & 3.60 & 3.60 \\
\hline
\end{tabular}

*Compared to $12800 \mathrm{AU} / \mathrm{mL}$ (accepted as $100 \%$ ) recorded in MRS broth (Biolab)

Tryptone $(20 \mathrm{~g} / \mathrm{L})$, or a combination of tryptone and yeast extract (1:0.6), added to basal MRS medium yielded a bacteriocin level of $12800 \mathrm{AU} / \mathrm{mL}$ (Table 2). Growth in the presence of a combination of tryptone and meat extract $(1: 0.6)$ reduced bacteriocin production by $50 \%$. Growth in the presence of yeast extract $(20 \mathrm{~g} / \mathrm{L})$ resulted in $6400 \mathrm{AU} / \mathrm{mL}$, or in the presence of meat extract $(20 \mathrm{~g} / \mathrm{L})$ or a combination of meat extract and yeast extract (1:1), resulted in bacteriocin production of 3200AU/mL (Table 2).

Tryptone is the key nitrogen source needed for optimal production of bacteriocin AMA-K. Similar results have been reported for the production of plantaricin 423 (46), bacteriocin ST712BZ (40) and for bacteriocins ST151BR and ST112BR $(35,38)$. In the case of plantaricin 423 , optimal bacteriocin production was recorded in MRS broth supplemented with bacteriological peptone, followed by casamino acids, tryptone and meat extract. Stimulation of bacteriocin production by yeast extract and meat extract has been reported for helveticin J (17). As far as we could determine, this is the first indication that tryptone is the key nitrogen source needed in the production of L. plantarum bacteriocins.

Growth of $L$. plantarum AMA-K in the presence of glucose $(20.0$, and $50.0 \mathrm{~g} / \mathrm{L}$ ) yielded $12800 \mathrm{AU} / \mathrm{mL}$ of bacteriocin AMA$\mathrm{K}$ (Table 2). Increased bacteriocin production (25600AU/ml) was recorded in the presence of $30 \mathrm{~g} / \mathrm{L}$ glucose. Lower concentrations of glucose $(5.0 \mathrm{~g} / \mathrm{L}$ and $10.0 \mathrm{~g} / \mathrm{L})$ yielded $3200 \mathrm{AU} /$ $\mathrm{mL}$ and $6400 \mathrm{AU} / \mathrm{mL}$, respectively (Table 2 ). Growth in the presence of maltose $(20.0 \mathrm{~g} / \mathrm{L})$ and sucrose $(20.0 \mathrm{~g} / \mathrm{L})$ yielded the same activity as $20.0 \mathrm{~g} / \mathrm{L}$ glucose (Table 2 ). Growth in the presence of mannose $(20.0 \mathrm{~g} / \mathrm{L})$ and fructose $(20.0 \mathrm{~g} / \mathrm{L})$ reduced bacteriocin production by $75 \%$, i.e. to $3200 \mathrm{AU} / \mathrm{mL}$. In the presence of $20.0 \mathrm{~g} / \mathrm{L}$ lactose and $20.0 \mathrm{~g} / \mathrm{L}$ gluconate reduction in bacteriocin AMA-K production was even higher, i.e. 1600AU/ $\mathrm{mL}$. These results are surprising, since this strain was isolated from a fermented milk product, but this indicates that bacteriocin production is dependent on combination of factors. Based on these results, the production of bacteriocin AMA-K is stimulated when cells are grown in medium supplemented with $30.0 \mathrm{~g} / \mathrm{L}$ glucose. 
Todorov, S.D.

Table 2. Influence of organic nitrogen, carbohydrates, growth medium and potassium on the production of bacteriocin AMA-K.

\begin{tabular}{|c|c|c|c|}
\hline Component & Concentration $(\mathrm{g} / \mathrm{L})$ & $\mathrm{pH}$ & Bacteriocin activity $(\mathrm{AU} / \mathrm{mL})$ \\
\hline Tryptone & 20.0 & 3.84 & 12800 \\
\hline Meat extract & 20.0 & 3.78 & 3200 \\
\hline Yeast extract & 20.0 & 3.84 & 6400 \\
\hline Tryptone + meat extract & $12.5+7.5$ & 3.83 & 6400 \\
\hline Tryptone + yeast extract & $12.5+7.5$ & 3.71 & 12800 \\
\hline Meat extract + yeast extract & $10.0+10.0$ & 3.76 & 3200 \\
\hline Tryptone + meat extract + yeast extract & $10.0+5.0+5.0$ & 3.54 & 12800 \\
\hline Glucose & 5.0 & 3.64 & 3200 \\
\hline -”- & 10.0 & 3.59 & 6400 \\
\hline -"- & 20.0 & 3.54 & 12800 \\
\hline -”- & 30.0 & 3.52 & 25600 \\
\hline -”- & 50.0 & 3.50 & 12800 \\
\hline Fructose & 20.0 & 3.73 & 3200 \\
\hline Sucrose & 20.0 & 3.66 & 12800 \\
\hline Maltose & 20.0 & 3.63 & 12800 \\
\hline Mannose & 20.0 & 3.62 & 3200 \\
\hline Lactose & 20.0 & 3.53 & 1600 \\
\hline Gluconate & 20.0 & 5.23 & 1600 \\
\hline Glycerol & 0 & 3.54 & 12800 \\
\hline -"- & 1.0 & 3.66 & 12800 \\
\hline -"- & 5.0 & 3.67 & 6400 \\
\hline -"- & 10.0 & 3.70 & 1600 \\
\hline .”- & 20.0 & 3.68 & 800 \\
\hline -”- & 50.0 & 3.68 & 200 \\
\hline MRS & 50.0 & 3.54 & 12800 \\
\hline BHI & 37.0 & 5.79 & 1600 \\
\hline M17 & 42.5 & 559 & 1600 \\
\hline Soy flour & 100.0 & 4.47 & 0 \\
\hline Molasses & 100.0 & 4.33 & 800 \\
\hline -"- & 20.0 & 3.89 & 0 \\
\hline $\mathrm{K}_{2} \mathrm{HPO}_{4}+\mathrm{KH}_{2} \mathrm{PO}_{4}$ & $2.0+2.0$ & 3.70 & 6400 \\
\hline $\mathrm{K}_{2} \mathrm{HPO}_{4}$ & 2.0 & 3.54 & 12800 \\
\hline$=$ & 5.0 & 3.73 & 3200 \\
\hline -"- & 10.0 & 3.93 & 3200 \\
\hline -”- & 20.0 & 4.38 & 400 \\
\hline $\mathrm{KH}_{2} \mathrm{PO}_{4}$ & 2.0 & 3.66 & 6400 \\
\hline -"- & 5.0 & 3.82 & 1600 \\
\hline -"- & 10.0 & 3.69 & 400 \\
\hline -”- & 20.0 & 3.75 & 0 \\
\hline Magnesium sulphate & 0 & 3.48 & 1600 \\
\hline Manganese sulphate & 0 & 3.80 & 3200 \\
\hline Tri-ammonium citrate & 0 & 3.63 & 3200 \\
\hline -”- & 2.0 & 3.54 & 12800 \\
\hline -”- & 5.0 & 3.54 & 12800 \\
\hline -”- & 10 & 4.04 & 3200 \\
\hline Tween 80 & 0 & 3.60 & 3200 \\
\hline -"- & 0.5 & 3.59 & 6400 \\
\hline -"- & 1.0 & 3.58 & 12800 \\
\hline -"- & 1.5 & 3.88 & 12800 \\
\hline -”- & 2.0 & 3.86 & 12800 \\
\hline
\end{tabular}




\begin{tabular}{|c|c|c|c|}
\hline \multicolumn{4}{|c|}{$(\mathrm{mg} / \mathrm{mL})$} \\
\hline Thiamine $\left(\right.$ Vit. $\left.B_{1}\right)$ & 1.0 & 3.65 & 6400 \\
\hline L-ascorbic acid (Vit. C) & 1.0 & 3.66 & 6400 \\
\hline Control & 0 & 3.54 & 12800 \\
\hline
\end{tabular}

*Compared to $12800 \mathrm{AU} / \mathrm{mL}$ (accepted as 100\%) recorded in MRS broth (Biolab)

Bacteriocin AMA-K production was affected differently by the presence of different concentrations of $\mathrm{K}_{2} \mathrm{HPO}_{4}$ or $\mathrm{KH}_{2} \mathrm{PO}_{4}$. Optimal bacteriocin AMA-K production (12800AU/mL) was recorded in the presence of $2.0 \mathrm{~g} / \mathrm{L} \mathrm{K} \mathrm{K}_{2} \mathrm{HPO}_{4}$. Higher concentrations $\mathrm{K}_{2} \mathrm{HPO}_{4}$ had a negative effect on bacteriocin AMA-K production (Table 2). However, replacing $\mathrm{K}_{2} \mathrm{HPO}_{4}$ with $\mathrm{KH}_{2} \mathrm{PO}_{4}$ resulted in reduction of bacteriocin AMA-K production (Table 2). A combination of $\mathrm{K}_{2} \mathrm{HPO}_{4}$ and $\mathrm{KH}_{2} \mathrm{PO}_{4}(2.0 \mathrm{~g} / \mathrm{L}$ and $2.0 \mathrm{~g} / \mathrm{L})$ resulted in the reduction of bacteriocin AMA-K by $50 \%$ (Table 2). In the case of plantaricin UG1, 7.0g/L K $\mathrm{HPO}_{4}$ resulted in increased activity (13). Different concentrations of $\mathrm{K}_{2} \mathrm{HPO}_{4}$ and $\mathrm{KH}_{2} \mathrm{PO}_{4}$ did not significantly affect production of bacteriocin ST712BZ, produced by L. pentosus ST712BZ (40). In the case of bacteriocin ST112BR, higher levels of activity was recorded when the medium contained $5.0 \mathrm{~g} / \mathrm{L}, 10.0 \mathrm{~g} / \mathrm{L}$ and $20.0 \mathrm{~g} / \mathrm{L} \mathrm{KH} \mathrm{KHO}_{4}$ (23). The optimal concentration of $\mathrm{K}_{2} \mathrm{HPO}_{4}$ required for plantaricin $\mathrm{ST} 31$ production was between $2.0 \mathrm{~g} / \mathrm{L}$ and $5.0 \mathrm{~g} / \mathrm{L}$ (37).

Production of bacteriocin AMA-K was the highest $(12800 \mathrm{AU} / \mathrm{mL})$ in the absence or in presence of very low $(1.0 \mathrm{~g} /$ L) concentration of glycerol (Table 2). Glycerol concentrations of $5.0 \mathrm{~g} / \mathrm{L}$ and higher (up to $50.0 \mathrm{~g} / \mathrm{L}$ ) led to progressively decreased levels of bacteriocin AMA-K production (Table 2). Similar results were reported for the production of bacteriocins ST151BR, ST112BR, ST712BZ and plantaricin ST31 $(35,37$, $38,40)$. An increase in glycerol leads to a lowering in water activity. The production of bacteriocin AMA-K may be influenced by osmotic stress or by binding of bacteriocin to the cell membranes or other molecules, initiated by presence of the glycerol.

Optimal bacteriocin AMA-K production was recorded in presence of $1.0 \mathrm{~g} / \mathrm{L}, 1.5 \mathrm{~g} / \mathrm{L}$ and $2.0 \mathrm{~g} / \mathrm{L}$ Tween 80 . Lower concentrations of Tween 80 have a negative effect on bacteriocin AMA-K production (Table 2).

Production of bacteriocin AMA-K requires the presence of magnesium sulphate and manganese sulphate as a part of the production medium. Exclusion of these salts resulted in reduction of bacteriocin AMA-K production (Table 2). Similar results were recorded for the effect of tri-ammonium citrate. Normally this component is present in MRS medium at a level of $2.0 \mathrm{~g} / \mathrm{L}$. At this concentration optimal bacteriocin AMA-K production was recorded. Exclusion of tri-ammnium citrate from the media formula resulted in reduction of bacteriocin activity to $3200 \mathrm{AU} / \mathrm{mL}$. However, increasing the concentration to $10.0 \mathrm{~g} / \mathrm{L}$ had a similar effect on bacteriocin AMA-K production (3200AU/ml, Table 2).

Reduction in bacteriocin AMA-K production to 6400AU/ $\mathrm{mL}$ was recorded in the presence of Vit. $\mathrm{B}_{1}$ or DL-6,8-thioctic acid (Table 2). However, a decrease to 3200AU/ml was recorded then MRS were supplemented with Vit. $B_{12}$ or Vit. C (Table 2). In the case of bateriocin ST194BZ, produced by L. plantarum ST194BZ, vitamins Vit. $B_{12}$ and Vit. $B_{1}$ had no effect on bacteriocin production, but addition of Vit. C or DL-6,8-thioctic acid had a negative effect, reducing the bacteriocin ST194BZ production with $50 \%$ (36).

The addition of $25600 \mathrm{AU} / \mathrm{ml}$ bacteriocin AMA-K to a 3-hold culture of L. innocua LMG13568, L. ivanovii subsp. ivanovii ATCC19119 and L. monocytogenes ScottA $\left(\mathrm{OD}_{600 \mathrm{~nm}}=0.1\right)$ resulted in growth inhibition for $9 \mathrm{~h}$ (Fig. 2), suggesting that the mode of activity of bacteriocin AMA-K is bacteriocidal. Addition of the same concentration of bacteriocin AMA-K to stationaryphase cells of L. innocua LMG13568, L. ivanovii subsp. ivanovii ATCC19119 and L. monocytogenes ScottA, resulted in no significant growth inhibition (results not shown). This suggested that bacteriocin AMA-K is only active against actively growing cells.

Bacteriocin AMA-K was adsorbed at $75 \%$ to cells of $L$. innocua LMG13568, L. monocytogenes ScottA and L. ivanovii subsp. ivanovii ATCC19119. (Table 3). Different levels of adsorption was observed in our previous study for bacHV219, but in general highest levels were observed in adsorption to sensitive strains compared to strains resistant to the effect of bacteriocin (42). Similar results have been reported for pediocin N5p (24), viz. 100\% adsorption to sensitive cells of $O$. oeni X2L, $80 \%$ to Lactobacillus hilgardii and $O$. oeni L10, and $70 \%$ to $L$. hilgardii 6D (24). Adsorption of pediocin N5p to resistant bacteria was below $20 \%$ (24). Buhnericin LB adsorbed $100 \%$ to sensitive cells of L. plantarum, Pediococcus dextranicus, $O$. oeni and E. faecalis, but also $100 \%$ to an insensitive strain of Pediococcus cerevisiae (47). In the case of plantaricin 423, adsorption ranged from $17 \%$ for Streptococcus caprinus ATCC 700066 to $67 \%$ for L. plantarum LMG 13556, L. curvatus DF38, L. innocua LMG 13568 and L. sakei DSM 20017 (39). Strains sensitive to plantaricin 423 adsorbed the peptide stronger (39). 


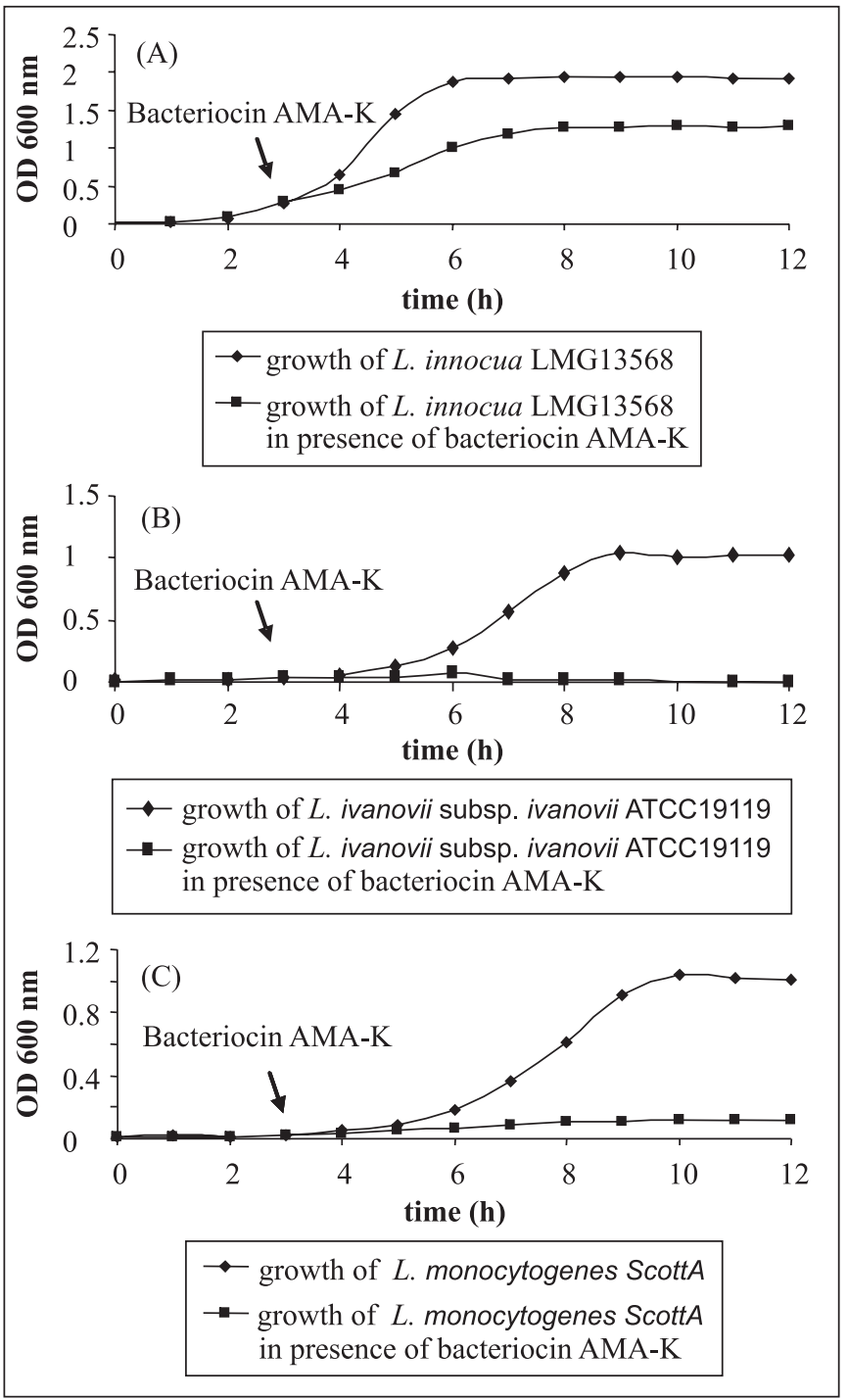

Figure 2. Effect of bacteriocin AMA-K on (A) L. innocua LMG13568, (B) L. ivanovii susbp. ivanovii ATCC19119 and (C) $L$. monocytogenes ScottA. (- -$)$ represent the growth of $L$. innocua LMG13568, L. monocytogenes ScottA and L. ivanovii subsp. ivanovii ATCC19119 without added bacteriocins (controls) and (- $\square$-) growth with added bacteriocin AMA-K after $3 \mathrm{~h}$. The arrow indicates the point at which the bacteriocins were added.

Optimal adsorption of bacteriocin AMA-K (75\%) to $L$. innocua LMG13568, L. monocytogenes ScottA and L. ivanovii subsp. ivanovii ATCC19119 were recorded at $\mathrm{pH}$ 7.0. lower levels of $\mathrm{pH}$ (3.5) resulted in reduction of the adsorption of bacteriocin AMA-K to this Listeria species to $50 \%$. However, in an experiment at $\mathrm{pH} 5.5$, reduction to $50 \%$ were recorded for adsorption to L. innocua LMG13568 and to L. monocytogenes
ScottA, but no change in level of adsorption was recorded for L. ivanovii susbp. ivanovii ATCC19119 (Table 3). These results show the potential of the application of this bacteriocin at neutral or moderate acid $\mathrm{pH}$. Differences in adsorption affected by $\mathrm{pH}$ rates may be due to specific interaction between bacteriocin AMA-K and the target strain. In the case of buchnericin LB, optimal adsorption to $L$. plantarum was recorded at $\mathrm{pH} 5.0-8.0$ (47). Optimal adsorption of plantaricin 423 to E. faecium HKLHS was recorded between $\mathrm{pH} 8.0$ and 10.0, and to L. sakei DSM20017 between $\mathrm{pH} 2.0$ and 6.0 (39).

Temperature has effect on bacteriocin AMA-K adsorption to L. innocua LMG13568, L. monocytogenes ScottA and $L$. ivanovii susbp. ivanovii ATCC 19119 . At $30^{\circ} \mathrm{C}$ and $37^{\circ} \mathrm{C}$ levels of $75 \%$ adsorption were observed for all tested Listeira species (Table 3). At $45^{\circ} \mathrm{C}$ increased adsorption of bacteriocin AMA-K was recorded to cells of L. ivanovii susbp. ivanovii ATCC19119 (87.5\%) and to L. monocytogenes ScottA (100\%) (Table 3). However, temperature of $4^{\circ} \mathrm{C}$ and $15^{\circ} \mathrm{C}$ resulted in reduction to $50 \%$ of adsorption of bacteriocin AMA-K to cells of L. innocua LMG13568 and L. ivanovii subsp. ivanovii ATCC19119 (Table 3). It was previously reported for bacHV219 that an increase in temperature from $25^{\circ} \mathrm{C}$ to $60^{\circ} \mathrm{C}$ had a negative effect on the adsorption of bacHV219 to E. faecium HKLHS. Forty percent adsorption was recorded between $25^{\circ} \mathrm{C}$ and $60^{\circ} \mathrm{C}$, with optimum adsorption $(80 \%)$ at $4^{\circ} \mathrm{C}$. Complete adsorption $(100 \%)$ to $E$. faecalis $\mathrm{E} 88$ was recorded after treatment at $4^{\circ} \mathrm{C}, 10^{\circ} \mathrm{C}, 45^{\circ} \mathrm{C}$ and $60^{\circ} \mathrm{C}$. A $20 \%$ decrease in adsorption was recorded at $37^{\circ} \mathrm{C}(42)$.

Adsorption was affected by temperature. Similar results were observed for other bacteriocins. In the case of buchnericin LB, identical adsorption levels to cells of $L$. plantarum was recorded after treatment at $0,10,25,50$ and $80^{\circ} \mathrm{C}$ (47). Changes in temperature had no effect on the adsorption of plantaricin 423 to E. faecium HKLHS (50).

Decreased adsorption of bacteriocin AMA-K to L. innocua LMG13568, L. monocytogenes ScottA and L. ivanovii susbp. ivanovii ATCC19119 was observed in the presence of Tween 20, Tween 80 and different concentrations of $\mathrm{NaCl}$ (Table 3). Ascorbic acid and potassium sorbate not effect adsorption of bacteriocin AMA-K to cells of $L$. innocua LMG1568, but reduced this process to cells of $L$. monocytogenes Scott and to L. ivanovii subsp. ivanovii ATCC19119 (Table 3). The presence of $1 \%$ sodium nitrate increased adsorption of bacteriocin AMA-K to cells of $L$. innocua LMG13568 and $L$. monocytogenes ScottA (Table 3). Increased adsorption of bacHV219 to E. faecium HKLHS was detected in the presence of Triton X-100, $\beta$-mercapto-ethanol, chloroform, $\mathrm{NaCl}$, $\mathrm{KH}_{2} \mathrm{PO}_{4}$ and $\mathrm{MgCl}_{2}$ (42). Adsorption of bacHV219 to E. faecalis E88 increased in the presence of Na-acetate, $\mathrm{Na}_{2} \mathrm{CO}_{3}$, Triton $\mathrm{X}-100,80 \%$ ethanol, methanol, $\mathrm{K}_{2} \mathrm{HPO}_{4}, \mathrm{KH}_{2} \mathrm{PO}_{4}, \mathrm{MgCl}_{2}, \mathrm{KCl}$, Tris and $\mathrm{NH}_{4}$-citrate (42).

An increase in the adsorption of plantaricin 423 to $E$. faecium HKLHS was observed in the presence of Triton X-100, Triton 
X-114 and chloroform (39). Adsorption of bacHV219 to E. faecalis E88 increased in the presence of Naacetate, $\mathrm{Na}_{2} \mathrm{CO}_{3}$, Triton X-100, 80\% ethanol, methanol, $\mathrm{K}_{2} \mathrm{HPO}_{4}, \mathrm{KH}_{2} \mathrm{PO}_{4}, \mathrm{MgCl}_{2}, \mathrm{KCl}$, Tris and $\mathrm{NH}_{4}$-citrate. $L$. sakei DSM 20017 treated with $\mathrm{NaCl}, \mathrm{K}_{2} \mathrm{HPO}_{4}, \mathrm{KH}_{2} \mathrm{PO}_{4}$, $\mathrm{MgCl}_{2}, \mathrm{KCl}, \mathrm{KI}$, Tris, NH4-citrate, $\mathrm{Na}_{2} \mathrm{CO}_{3}$, SDS, $\beta$ mercapto-ethanol, $80 \%$ ethanol and methanol led to a reduction in the adsorption of plantaricin 423 (39). No change in adsorption was observed in the presence of Na-acetate or EDTA, whereas an increase in adsorption was observed in the presence of Triton X100, Triton X-114 and chloroform (39). Adsorption of buchnericin $\mathrm{LB}$ to $L$. plantarum was reduced by $\mathrm{NaCl}$, $\mathrm{NH}_{4} \mathrm{Cl}, \mathrm{MgCl}_{2}, \mathrm{KCl}, \mathrm{KI}$ and Tris. Treatment of cells with $\mathrm{NH}_{4}$-citrate, Na-acetate, $\mathrm{NaCO}_{3}$, EDTA SDS, triton$\mathrm{X}, 2$-mercapto-ethanol, $80 \%$ ethanol and $80 \%$ methanol had no effect on adsorption of buchnericin LB to $L$. plantarum (47). Adsorption of pediocin N5p to $P$. pentosaceus $\mathrm{E} 5 \mathrm{p}$ increased in the presence of $\mathrm{MgCl}_{2}$, $\mathrm{MgSO}_{4}, \mathrm{MnCl}_{2}, \mathrm{MnSO}_{4}$, whereas $\mathrm{NaCl}, \mathrm{KCl}, \mathrm{KI}, \mathrm{NH}_{4} \mathrm{Cl}$, $\mathrm{CaCl}_{2}, \mathrm{Na}_{3} \mathrm{PO}_{4}, \mathrm{Na}_{2} \mathrm{SO}_{4}$, EDTA and ethanol had no affect on adsorption (31). Organic salts and $\mathrm{Na}$-acetate reduced pediocin N5p adsorption to target cells. Adsorption of pediocin N5p increased with $25 \%$ in the presence of SDS (24).

L. plantarum AMA-K has a 1044bp fragment corresponding to that recorded for pediocin PA-1 (Fig. 3A). Digestion with $X h o I$ and HindIII showed that the purified PCR product differed from that obtained for L. plantarum 423 (Fig. 3B). The PCR product from $L$. plantarum 423 was digested to 2 fragments by XhoI. However, the PCR product from $L$. plantarum AMAK DNA was digested to 2 products only by HindIII. The difference in digested profiles were expected based on the genetic sequence of the genes of plantaricin 423 and pediocin PA-1 (45). The sequences of the PCR product using DNA from $L$. plantarum AMA-K was identical to that reported for pediocin PA-1 (25). Pediocin PA-1 biosynthesis involves a DNA fragment of approximately $3.5 \mathrm{~kb}$, comprising the four genes pedA, pedB, pedC, and pedD (25). This results show that bacteriocin AMA-K share high homology to pediocin PA-1.

\section{CONCLUSIONS}

Bacteriocin AMA-K inhibits the growth of $E$. faecalis, E. mundtii, E. coli, K. pneumoniae, L. lactis subsp. lactis, L. casei, L. curvatus, L. sakei, E. faecium, L. innocua, L. monocytogenes and L. ivanovii subsp. ivanovii. Growth of strain AMA-K in BHI, M17, soy milk and molasses was similar to growth in MRS.
Table 3. Effect of temperature, $\mathrm{pH}$ and chemicals on adsorption of bacteriocin AMA-K to L. innocua LMG13568, L. ivanovii susp. ivanovii ATCC19119 and L. monocytogenes ScottA.

\begin{tabular}{lccc}
\hline \multicolumn{5}{c}{$\begin{array}{c}\text { L. innocua } \\
\text { LMG 13568 }\end{array}$} & $\begin{array}{c}\text { L. ivanovii } \\
\text { susbp. ivanovii } \\
\text { ATCC 19119 }\end{array}$ & Lonocytogenes \\
& \multicolumn{3}{c}{ ScottA } \\
\hline \multicolumn{2}{l}{ Effect of temperatures $\left({ }^{\circ}\right.$ C): } & & \\
4 & 50 & 50 & 75 \\
15 & 50 & 50 & 75 \\
30 & 75 & 75 & 75 \\
37 & 75 & 75 & 75 \\
45 & 75 & 87.5 & 100 \\
\hline$p H$ & & & \\
3.5 & 50 & 50 & 50 \\
5.5 & 50 & 75 & 50 \\
7.0 & 75 & 75 & 75 \\
\hline
\end{tabular}

\section{Chemicals (1\%)}

\begin{tabular}{lccc} 
Tween 80 & 25 & 25 & 25 \\
Tween 20 & 25 & 25 & 50 \\
Ascorbic acid & 75 & 50 & 50 \\
Potassium sorbate & 75 & 50 & 50 \\
Sodium nitrate & 87.5 & 75 & 87.5 \\
$\mathrm{NaCl}(0.5 \%, 1.0 \%$, & 50 & 50 & 50 \\
$1.5 \%$ and $2.0 \%)$ & & & \\
\hline
\end{tabular}

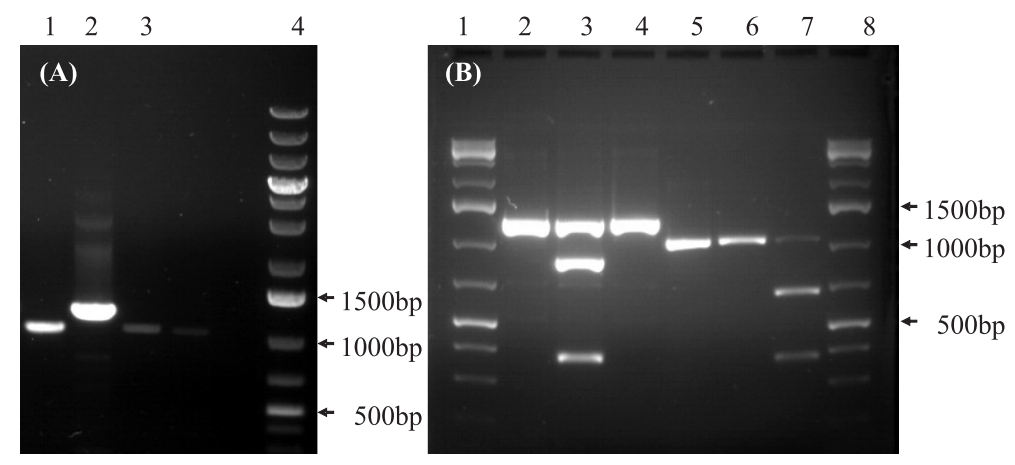

Figure 3. PCR plantaricin and restriction

GEL (A): DNA banding patterns obtained after PCR with primers to PA1 genes. Lane 1: Strain $L$. plantarum AMA-K $(10 \mu \mathrm{L}$ PCR product loaded), lane 2: Strain L. plantarum 423 (10 $\mu \mathrm{L}$ PCR product loaded), lane 3: Strain $L$. plantarum AMA-K ( $3 \mu \mathrm{L}$ PCR product loaded), Line 4: O'GeneRuler ${ }^{\mathrm{tm}} 1 \mathrm{~kb}$ DNA Ladder (Fermentas).

GEL (B): Restriction enzyme analysis using XhoI and HindIII. Lines 1 and 8: O'GeneRuler ${ }^{\mathrm{tm}} 1 \mathrm{~kb}$ DNA Ladder (Fermentas); line 2: plantaricin 423-uncut; line 3: plantaricin 423-XhoI; line 4: plantaricin 423-HindIII; line 5: bacteriocin AMA-K-uncut; line 6: bacteriocin AMA-K-XhoI; line 7: bacteriocin AMA-K-HindIII. 
Optimal bacteriocin production was recorded in MRS broth with an initial $\mathrm{pH}$ of 6.0 and 5.5. After $20 \mathrm{~h}$ of incubation in all media compositions tested, MRS supplemented with tryptone $(20.0 \mathrm{~g} /$ $\mathrm{L})$, tryptone and yeast extract $(12.5 \mathrm{~g} / \mathrm{L}$ and $7.5 \mathrm{~g} / \mathrm{L})$, glucose (20.0 and 50.0g/L), sucrose $(20.0 \mathrm{~g} / \mathrm{L})$, maltose $(20 \mathrm{~g} / \mathrm{L})$, glycerol (up to $1.0 \mathrm{~g} / \mathrm{L}$ ), $\mathrm{K}_{2} \mathrm{HPO}_{4}(2.0 \mathrm{~g} / \mathrm{L})$, tri-ammonium citrate $(5.0 \mathrm{~g} / \mathrm{L}$ ) yielded $12800 \mathrm{AU} / \mathrm{mL}$. Glucose at $30 \mathrm{~g} / \mathrm{L}$ increased bacteriocin AMA-K production by $100 \%$. Optimal adsorption of bacteriocin AMA-K (75\%) to Listeria strains was recorded at $\mathrm{pH}$ 7.0. However, temperatures of $4{ }^{\circ} \mathrm{C}$ and $15^{\circ} \mathrm{C}$ resulted in reduction of $50 \%$ of adsorption of bacteriocin AMA-K to cells of $L$. innocua LMG13568 and L. ivanovii subsp. ivanovii ATCC19119. Decreased adsorption of bacteriocin AMA-K to Listria strains was observed in the presence of Tween 20, Tween 80 and different concentrations of $\mathrm{NaCl}$. Ascorbic acid and potassium sorbate did not effect adsorption of bacteriocin AMA-K to cells of $L$. innocua LMG1568, but reduced this process in cells of $L$. monocytogenes Scott and to L. ivanovii subsp. ivanovii ATCC19119. The presence of $1 \%$ sodium nitrate increased adsorption of bacteriocin AMA-K to cells of L. innocua LMG13568 and L. monocytogenes ScottA. Bacteriocin AMA-K shares high homology to pediocin PA-1.

\section{ACKNOWLEDGMENTS}

The research was supported by Claude Leon Foundation, Cape Town, South Africa. The author is grateful to Dr. Carol van Reenen for discussions about bio-molecular work and to Prof. Leon M.T. Dicks for using his laboratory facilities.

\section{RESUMO}

\section{Otimização da produção de bacteriocina por Lactobacillus plantarum AMA-K isolado de Amasi, um produto lácteo fermentado de Zimbabwe, e estudo da adsorção da bacteriocina AMA-K à Listeria innocua, Listeria monocytogenes e Listeria ivanovii subsp.ivanovii}

A bacteriocinaAMA-K produzida por Lactobacillus plantarum AMA-K inibe a multiplicação de Enterococcus spp, Escherichia coli, Klebsiella pneumoniae e Listeria spp. A multiplicação da cepa AMA-K em BHI, leite de soja e melaço foi semelhante à multiplicação em MRS. O efeito de fontes de nitrogênio orgânico, carboidratos, glicerol, $\mathrm{K}_{2} \mathrm{HPO}_{4} \mathrm{e} \mathrm{KH}_{2} \mathrm{PO}_{4}$, $\mathrm{MgSO}_{4}, \mathrm{MnSO}_{4}$, citrato de triamônio, Tween 80, vitaminas e pH inicial sobre a bacteriocina AMA-K foi determinada. O modo de ação da bacteriocina AMA-K foi estudado. O efeito da bacteriocina AMA-K sobre Listeria innocua LMG13568, Listeria ivanovii subsp.ivanovii ATCC19119 e Listeria monocytogenes Scott A foi determinado. A adsorção da bacteriocina AMA-K às células-alvo em diferentes temperaturas,
pH e na presença de Tween 20, Tween 80, ácido ascórbico, sorbato de potássio, nitrato de sódio a cloreto de sódio foi avaliada. A bacteriocina AMA-K apresenta grande homologia a pediocina PA-1.

Palavras-chave: bacteriocina AMA-K, Lactobacillus plantarum, amasi

\section{REFERENCES}

1. Aasen, I.M.; Moreto, T.; Katla, T.; Axelsson, L.; Storro, I. (2000). Influence of complex nutrients, temperature and $\mathrm{pH}$ on bacteriocin production by Lactobacillus sakei CCUG 42687. Appl. Microbiol. Biotechnol., 53: 159-166.

2. Abriouel, H.; Valdivia, E.; Galvez, A.; Maqueda, M. (2001). Influence of physico-chemical factors on the oligomerization and biological activity of bacteriocin AS-48. Curr. Microbiol., 42: 89-95.

3. Audisto, M.C.; Oliver, G.; Apella, M.C. (2001). Effect of different complex carbon sources on growth and bacteriocin synthesis of Enterococcus faecium. Int. J. Food Microbiol., 63: 235-241.

4. Beukes, E.M.; Bester, B.H.; Mostert, J.F. (2001). The Microbiology of South African traditional fermented milks. Int. J. Food Microbiol., 63: 189-197.

5. Biswas, S.R.; Ray, P.; Johnson, M.C.; Ray, B. (1991). Influence of growth conditions on the production of a bacteriocin, pediocin $\mathrm{AcH}$ by Pediococcus acidilactici H. Appl. Environ. Microbiol., 57: 1265-1267.

6. Bogovic-Matijasic, B.; Rogelj, I. (1998). Bacteriocin complex of Lactobacillus acidophilus LF221 - production studies in MRS-media at different $\mathrm{pH}$-values and effect against Lactobacillus helveticus ATCC 15009. Process Biochem., 33: 345-352.

7. Chin, H.S.; Chin, J.S.; Kim, J.M.; Yang, R.; Yoon, S.-S. (2001). Detection and antibacterial activity of a bacteriocin produced by Lactobacillus plantarum. Food Sci. Biotech., 10: 335-341.

8. Daeschel, M.A.; McKeney, M.C.; McDonald, L.C. (1990). Bacteriocidal activity of Lactobacillus plantarum C-11. Food Microbiol., 7: 91-98.

9. De Man, J.C.; Rogosa, M.; Sharpe, M.E. (1960). A medium for the cultivation of lactobacilli. J. Appl. Bacteriol., 23: 130-135.

10. De Vuyst L.; Vandamme E. (1994). Bacteriocins of lactic acid bacteria (Blackie London, United Kingdom pp. 539

11. De Vuyst, L.; Callewaert, R.; Crabbe, K. (1996). Primary metabolite kinetics of bacteriocin biosynthesis by Lactobacillus amylovorus and evidence for stimulation of bacteriocin production under unfavourable growth conditions. Microbiol., 142: 817-827.

12. Dellaglio, F.; Bottazzi, V.; Troatelli, L.D. (1973). Deoxyribonucleic acid homology and vase composition in some thermophylic lactobacilli. J. Gen. Microbiol., 74: 289-297.

13. Enan, G.; Essawy, A.A.; Uyttendaele, M.; Debevere, J. (1996). Antibacterial activity of Lactobacillus plantarum UG1 isolated from dry sausage: Characterization, production and bactericidal action of plantaricin UG1. Int. J. Food Microbiol., 30: 189-215.

14. Herranz, C.; Martinez, J.M.; Rodriguez, J.M.; Hernandez, P.E.; Cintas, L.M. (2001). Optimization of enterocin P production by batch fermentation of Enterococcus faecium P13 at constant pH. Appl. Microbiol. Biotechnol., 56: 378-383.

15. Heu, S.; Oh, J.; Kang, Y.; Ryu, S.; Cho, S.K.; Cho, Y.; Cho, M. (2001). Gly gene cloninig and expression and purification of Glycinecin A, a bacteriocin produced by Xanthomonas campestris pv. Glycines 8ra. Appl. Environ. Microbiol., 67, (9) 4105-4110.

16. Jimenez-Diaz R.; Rios-Sanchez R.M.; Desmazeaud M.; Ruiz-Barrba J.L.; Piard J.C. (1993). Plantaricin S and T, two new bacteriocins produced by Lactobacillus plantarum LPCO10 isolated from a green olive fermentation. Appl. Environ. Microbiol., 59: 1416-1424. 
17. Joerger, M.C.; Klaenhammer, T.R. (1986). Characterization and purification of helveticin $\mathrm{J}$ and evidence for chromosomally determined bacteriocin produced by Lactobacillus helveticus 481. J. Bacteriol., 167: 439-446.

18. Kato, T.; Matsuda, T.; Ogawa, E.; Ogawa, H.; Kato, H.; Doi, U.; Nakamura, R. (1994). Plantaricin-149, a bacteriocin produced by Lactobacillus plantarum NRIC 149. J. Ferment. Bioeng., 77: $277-$ 282.

19. Kelly, W.J.; Asmundson, R.V.; Huang, C.M. (1996). Characterization of plantaricin KW30, a bacteriocin produced by Lactobacillus plantarum. J. Appl. Bacteriol., 81: 657-662.

20. Kim, W.S.; Hall, R.J.; Dunn, N.W. (1997). The effect of nisin concentration and nutrient depletion on nisin production of Lactococcus lactis. Appl. Microbiol. Biotechnol., 50: 429-433.

21. Krier, F.; Revol-Junelles, A.M.; Germain, P. (1998). Influence of temperature and $\mathrm{pH}$ on production of two bacteriocins by Leuconostoc mesenteroides subsp. mesenteroides FR52 during batch fermentation. Appl. Microbiol. Biotechnol., 50: 359-363.

22. Leal-Sánchez, M.V.; Jiménez-Díaz, R.; Maldonado-Barragán, A.; Garrido-Fernández, A.; Ruiz-Barba, J.L. (2002). Optimization of bacteriocin production by batch fermentation of Lactobacillus plantarum LPCO10. Appl. Environ. Microbiol., 68: 4465-4471.

23. Leroy, F.; De Vuyst, L. (2003). A combined model to predict the functionality of the bacteriocin-producing Lactobacillus sakei strain CTC494, Appl. Environ. Microbiol., 69: 1093-1099.

24. Manca de Nadra, M.C.; Sandino de Lamelas, D.; Strasser de Saad, A.M. (1998). Pediocin N5p from Pediococcus pentosaceus: Adsorption on bacterial strains. Int. J. Food Microbiol., 39: 79-85.

25. Marugg, J.D.; Gonzalez, C.F.; Kunka, B.S.; Ledeboer, A.M.; Pucci, M.J.; Toonen, M.Y.; Walker, S.A.; Zoetmudler, L.C.M.; Vandenbergh, P.A. (1992). Cloning, expression, and nucleotide sequence of genes involved in the production of pediocin PA-1, a bacteriocin from Pediococcus acidilactici PAC1.0. Appl. Environ. Microbiol., 58: 2360-2367.

26. Mataragas, M.; Metaxopoulos, J.; Galiotou, M.; Drosinos, E.H. (2003). Influence of $\mathrm{pH}$ and temperature on growth and bacteriocin production by Leuconostoc mesenteroides L124 and Lactobacillus curvatus L442. Meat Sci., 64: 265-271.

27. Matsusaki, H.; Endo, N.; Sonomoto, K.; Ishizaki A. (1996). Lantibiotic nisin Z fermentative production by Lactococcus lactis IO-1: Relationship between production of the lantibiotic and lactate and cell growth. Appl. Microbiol. Biotechnol., 45: 36-40.

28. Mortverd-Abildgaard, C.I.; Nissen-Meyer, J.; Jelle, B.; Grenov, B.; Skaugen, M.; Nes, I.F. (1995). Production and pH-dependent bacteriocidal activity of lactocin S, a lantibiotic from Lactobacillus sake L45. Appl. Environ. Microbiol., 61: 175-179.

29. Motta, A.S.; Brandelli, A. (2003). Influence of growth conditions on bacteriocin production by Brevibacterium linens. Appl. Microbiol. Biotechnol., 62: 163-167.

30. Nel, H.A.; Bauer, R.; Vandamme, E.J.; Dicks, L.M.T. (2001). Growth optimisation of Pediococcus damnosus NCFB 1832 and the influence of $\mathrm{pH}$ and nutrients on the production of pediocin PD-1. J. Appl. Microbiol., 91: 1131-1138.

31. Nieto-Lozano, J.C.; Reguera-Useros, J.I.; Pelaez-Martinez, M.C.; De la Torre, A.H. (2002). Bacteriocinogenic activity from starter cultures used in Spanish meat industry. Meat Sci., 62: 237-243.

32. Parente, E.; Ricciardi, A. (1994). Influence of $\mathrm{pH}$ on the production of enterocin 1146 during batch fermentation. Lett. Appl. Microbiol., 19: $12-15$
33. Parente, E.; Ricciardi, A.; Addario, G. (1994). Influence of pH on growth and bacteriocin production by Lactococcus lactis subsp. lactis 140VWC during batch fermentation. Appl. Microbiol. Biotechnol., 41: 388-394.

34. Todorov, S.D.; Dicks, L.M.T. (2005). Lactobacillus plantarum isolated from molasses produces bacteriocins active against Gramnegative bacteria. Enzyme Microb Technol., 36: 318-326.

35. Todorov, S.D.; Dicks, L.M.T. (2004). Effect of medium components on bacteriocin production by Lactobacillus pentosus ST151BR, a strain isolated from beer produced by the fermentation of maize, barley and soy flour. World J. Microbiol. Biotechnol., 20: 643-650, 2004.

36. Todorov, S.D.; Dicks, L.M.T. (2005). Effect of growth medium on bacteriocin production by Lactobacillus plantarum ST194BZ, a strain isolated from boza. Food Technol. Biotechnol., 43: 165-173.

37. Todorov, S.; Gotcheva, B.; Dousset, X.; Onno, B.; Ivanova, I. (2000) Influence of growth medium on bacteriocin production in Lactobacillus plantarum ST31. Biotechnol. Biotechnol. Eq., 14: 50-55.

38. Todorov, S.D.; Dicks, L.M.T. (2004). Influence of growth medium on bacteriocin production by Lactobacillus pentosus ST112BR, a strain isolated from traditional South African beer. Proceedings of National conference with foreign participation, 3-4 Juny, 2004 Stara Zagora, Bulgaria. Volume IV, Human medicine. Part 1. Clinical and molecular biology, microbiology. Physiology and pharmacology. Publishing group: Stara Zagora Union of Scientists. 132-136.

39. Todorov, S.D.; Dicks, L.M.T. (2006). Parameters affecting the adsorption of plantaricin 423 , a bacteriocin produced by Lactobacillus plantarum 423 isolated from sorghum beer. Biotechnol. J., 1: 405-409.

40. Todorov, S.D.; Dicks, L.M.T. (2007). Bacteriocin production by Lactobacillus pentosus ST712BZ isolated from boza. Braz. J. Microbiol., 38: 166-172.

41. Todorov, S.D.; Dicks, L.M.T. (2006). Medium components effecting bacteriocin production by two strains of Lactobacillus plantarum ST414BZ and ST664BZ isolated from boza. Biologia, 61: 269-274.

42. Todorov, S.D.; Botes, M.; Danova, S.T.; Dicks, L.M.T. (2007). Probiotic properties of Lactococcus lactis subsp. lactis HV219, isolated from human vaginal secretions. J. Appl. Microbiol., 103: 629-639.

43. Todorov, S.D.; Nyati, H.; Meincken, M.; Dicks, L.M.T. (2007). Partial characterization of bacteriocin AMA-K, produced by Lactobacillus plantarum AMA-K isolated from naturally fermented milk from Zimbabwe. Food Control, 18: 656-664.

44. Todorov, S.D.; Van Reenen, C.A.; Dicks, L.M.T. (2004) Optimization of bacteriocin production by Lactobacillus plantarum ST13BR, a strain isolated from barley beer. J. Gen. Appl. Microbiol., 50: 149-157.

45. Van Reenen, C.A.; Van Zyl, W.H.; Chikindas, M.L.; Dicks, L.M.T. (2002). Characterization and heterologous expression of a class IIa bacteriocin, plantaricin 423 from Lactobacillus plantarum 423, in Saccharomyces cerevisiae. Int. J. Food Microbiol., 81: 29-40.

46. Verellen, T.L.J.; Bruggeman, G.; Van Reenen, C.A.; Dicks, L.M.T.; Vandamme, E.J. (1998). Fermentation optimisation of plantaricin 423, a bacteriocin produced by Lactobacillus plantarum 423. J. Ferment. Bioeng., 86: 174-179.

47. Yildirim, Z.; Av ar, Y.K.; Yildirim, M. (2002). Factors affecting the adsorption of buchnericin LB, a bacteriocin produced by Lactobacillus buchneri. Microb. Res., 157: 103-107. 